УДК 378.015.31:7:745/749

DOI:

Леонід Оршанський, доктор педагогічних наук, професор, завідувач кафедри технологічної та професійної освіти Дрогобицького державного педагогічного університету імені Івана Франка

\title{
ЕСТЕТИЧНА КУЛЬТУРА МАЙБУТНІХ ФАХІВЦІВ У ГАЛУЗІ ДИЗАЙНУ: СУТНІСТЬ ТА СТРУКТУРА
}

У статті розглядається проблема формування і розвитку естетичної культури майбутніх фахівців у галузі дизайну, зокрема сутність та структура иієї важливої якості особистості. Будучи складним системним духовно-функціональним утворенням, естетична культура майбутнього дизайнера спирається на суспільний досвід естетичного освоєння дійсності, знаходиться в стані динамічного розвитку, основою якого є механізм самоорганізачії, побудований на взаємозв'язку найважливіших його компонентів - емочійно-чуттєвого, потребнісно-мотивачійного, когнітивного і діяльнісного.

Ключові слова: естетична культура; структурно-функціональні компоненти; педагогічні мови; майбутній дизайнер.

Табл. 1. Літ. 13.

Leonid Orshanskiy, Doctor of Sciences (Pedagogy), Professor, Head of the Technological and Professional Education Department Drohobych Ivan Franko State Pedagogical University

\section{AESTHETIC CULTURE OF FUTURE PROFESSIONALS IN THE DESIGN INDUSTRY: ESSENCE AND STRUCTURE}

The article deals with the problem of formation and development of aesthetic culture of future specialists in the field of design, in particular the essence and structure of this important quality of personality.

It was found out that the aesthetic culture of the individual in terms of content and character is a complex socio-historical, cultural, educational and educational phenomenon. During the socio-historical past, it has shown the ability of a person to perceive, comprehend and create a beauty in the world, around the world and art. The aesthetic culture of the individual contributes to the accumulation of artistic and aesthetic ideas, works, and compositions, enriches the aesthetic experience of artists, and affects their aesthetic feelings, concepts, representations, values and outlook.

The theoretical analysis of the peculiarities of the aesthetic culture of the personality of the future designer makes it possible to consider it as an integral component of the aesthetic culture of society, personal quality and spiritual and functional education, which manifests itself at the level of formation of the aesthetic attitude to the surrounding world and its development "by the laws of beauty" in the process of creative artistic-project activity. Being a complex system of spiritual and functional education, the aesthetic culture of the future designer relies on the social experience of aesthetic development of reality, is in a state of dynamic development, the basis of which is the mechanism of self-organization, built on the interconnection of its most important components - emotionalsensory, needs-motivational, cognitive and activity.

On the basis of theoretical study of literary sources, three main pedagogical conditions for the formation and development of the aesthetic culture of the future designer are identified: the presence of aesthetic environment; a high level of aesthetic culture of scientific and pedagogical workers; organization of independent aesthetic activity on the development and implementation of a creative artistic project.

Keywords: aesthetic culture; structural and functional components; pedagogical languages; a future designer.

П остановка проблеми. Сьогодні відбувається зміна пріоритетів вітчизняної освіти в бік посилення іiі культуроцентричної ролі i, як наслідок, формування “людини культури” на всіх інституційних рівнях. В інформаційному суспільстві, поряд із розвитком інтелекту все більшого значення й актуальності набуває збагачення людини цінностями, творчою енергією і духовними силами, що є засадничою умовою її повноцінної життєдіяльності в сучасних соціокультурних реаліях. Ці положення співзвучні новій парадигмі реформування вищої художньої освіти (у т.ч. дизайнерської), в якій йдеться про відновлення, збереження і розвиток кращих мистецьких традицій, гармонійне використання потенціалу образотворчих, пластичних й інших видів мистецтв 3 метою розвитку у студентів високого рівня духовності та культури.

Вища дизайн-освіта $\epsilon$ важливою ланкою процесу становлення особистості фахівця, який 
володіючи природними нахилами та творчими здібностями, прагне естетичного перетворення себе самого і навколишньої дійсності. Звідси ключове завдання дизайн-освіти полягає у підготовці майбутніх дизайнерів із розвинутою здатністю сприймати, відчувати, цінувати та створювати “внутрішню і зовнішню красу”. Це зумовлює необхідність орієнтації вищої дизайносвіти передовсім на розвиток естетичної культури цієї категорії фахівців, які покликані естетично вдосконалити світ сучасного i майбутнього.

Аналіз літератури засвідчив існування різних підходів до визначення сутності та змісту процесу естетичного виховання, формування і розвитку естетичної культури особистості. Так, філософським проблемам в галузі естетики, естетичного виховання, формування естетичної культури присвячені фундаментальні праці О. Баумгартена, А. Бергсона, Ю. Борева, Г. Гегеля, Г. Гердера, Д. Даттона, І. Зязюна, М. Кагана, М. Киященко, С. Кримського, Б. Кроче, В. Кудіна, Л. Левчук, В. Мазепи, Т. Манро, Ж. Марітена, В. Михальова, О. Семашка, М. Хайдеггера, Й. Шіллера, Ф. Шеллінга й ін. Результати вивчення цих наукових джерел дають підстави стверджувати, що донині існують різні погляди і трактування поняття “естетична культура", часто пропонуються діаметрально протилежні підходи до визначення її структури, принципів формування і розвитку.

Історичні, теоретичні, практичні аспекти дизайну, процеси становлення і функціонування дизайн-освіти, особливості професійної підготовки та виховання майбутніх фахівців у галузі дизайну стали предметом чисельних досліджень, зокрема: Є. Антоновича, В. Аронова, М. Гізе, В. Глазічева, В. Даниленка, О. Дем'янчука, С. Кадубовської, С. Кожуховської, М. Курача, Ю. Легенького, Г. Мінервіна, С. Михайлова, А. Руденченко, В. Прусака, П. Татіївського, В. Томашевського, О. Фурси, О. Хмельовського, А. Чебикіна, М. Яковлева та ін.

Звідси проблема формування і розвитку естетичної культури майбутніх дизайнерів $€$ актуальною для сучасної педагогічної науки й освітньої практики. У багатьох нормативних і програмних документах задекларовано, що мистецькі заклади вищої освіти повинні здійснювати фахову підготовку майбутніх дизайнерів, які володіючи високим рівнем загальної й естетичної культури, здатні виявляти естетичне ставлення до навколишньої дійсності та мистецтва, глибоко сприймати, освоювати й збагачувати духовно-матеріальні цінності суспільства, організовувати творчу художньоконструкторську діяльність, здійснювати трансформацію сучасного світу “за законами краси".

Мета статі. Розкрити сутність естетичної культури та їі ключову роль у вихованні нової генерації дизайнерів.

Виклад основного матеріалу. Естетична культура - складне та багатогранне явище, що представляє собою одну $з$ основних складових загальної культури соціуму й, одночасно, окремий аспект кожної з цих складових. Це пояснює безліч підходів до наукового тлумачення цього поняття. Вперше термін "естетична культура" використав й намагався обгрунтувати Ф. Шиллер у своїй праці “Листи про естетичне виховання людини”. На його думку, лише цей феномен, будучи вищим рівнем розвитку загальної культури, може забезпечити цілісність та неповторність особистості, при цьому він не розділяв її на різні культурні шари: політичний, правовий, економічний, моральний, художній та ін. $[12,11]$. У подальшому в спеціальній літературі та педагогічних дослідженнях перевага здебільшого надавалася терміну “естетичне виховання", зміст якого спрямовувався на розвиток окремих складових естетичної культури.

Учені, що досліджують естетичну культуру, розглядають іï у трьох векторах наукової інтерпретаиіï:

- по-перше, естетична культура як соціальноісторичне явище (В. Адорно, В. Асмус, П. Гаврилюк, І. Зязюн, М. Каган, Н. Калашник, В. Мовчан, О. Оніщенко та ін.), коли на тривалих етапах розвитку суспільної практики в людини розвивалася здатність сприймати, осмислювати і творити красу навколишньої дійсності, готовність до естетичного самовдосконалення; вченими виокремлено основні етапи розвитку естетичної культури як соціально-історичного явища, починаючи від стародавніх часів, античного періоду й до становлення сучасного українського суспільства; ними обгрунтовано, що естетична культура має діалектичний зв'язок із соціальними процесами; визначено соціально-економічні умови, характерні для різних етапів розвитку суспільства; 3'ясовано, що естетична культура динамічно розвивається завдяки осмисленню, уточненню й збагаченню ключових понять, категорій, дефініцій і уявлень про красу, гармонійність, цілісність, органічність тощо; вона усвідомлюється суспільством як важливий чинник розвитку особистості, іiї ставлення до навколишнього світу та мистецтва; 
- по-друге, естетична культура як культурологічне явище (В. Бутенко, Л. Виготський, З. Гіптерс, А. Горєлов, А. Канарський, О. Колеснікова, Л. Столович, І. Туманов та ін.), коли вплив на розвиток духовної сфери суспільства, тобто основних видів і жанрів мистецтва (література, музика, хореографія, театр, кіно, образотворче і декоративно-ужиткове мистецтво, архітектура тощо) відбувається завдяки художньо-творчому процесу митців, котрі спрямовують творчі зусилля на розкриття різних аспектів життя та діяльності через художні образи й інші засоби впливу на свідомість людей; художня культура виконує важливу ціннісно-орієнтаційнуфункцію, допомагає виводити мистецький твір на рівень актуалізованих у суспільстві проблем, пропонує оптимальний рівень і характер їх сприйняття, осмислення та практичного розв'язання; вона органічно пов'язана 3 основними етапами художньо-творчого процесу, акумулює естетичні смаки та ідеї, сприяє створенню композиційної структури, спонукає до використання особливих засобів виразності тощо;

- по-третє, естетична культура як освітне й виховне явище (С. Антонович, Г. Апресян, О. Бабічев, В. Бітаєв, М. Верб, Л. Вишнякова, О. Дем'янчук, І. Зязюн, Є. Квятковський, Н. Кічук, Б. Ліхачев, С. Мельничук, Н. Миропольська, Б. Неменський, М. Овсянніков, Г. Падалка, Л. Побережна, О. Рудницька, М. Стась, Г. Шевченко, А. Щербо та ін.), коли здійснюється безпосередній вихід на особливу суспільну практику, пов'язану з організацією художньотворчого процесу в загальних і мистецьких закладах освіти, де особистість живе, працюе, навчається і виховується, маючи можливість розкрити свої потенційні сили, здібності і таланти, набути досвіду освоєння навколишньої дійсності “за законами краси".

На основі проведеного аналізу наукової літератури, присвяченої процесу розвитку естетичної культури особистості, можна зробити висновок про відсутність єдиного підходу до визначення сутності естетичної культури та їі структурних компонентів. Одні вчені відмовляються розглядати естетичну культуру як базовий компонент загальної культури особистості, інші - навпаки, визначаючи її як частину загальної культури, не аналізують їі конкретний вияв у різних компонентах. При цьому в більшості визначень поняття “естетична культура особистості”, поданих авторами досліджень, не відображена їі родова ознака естетичне ставлення до навколишньої дійсності.

Аналіз визначень “естетична культура", які запропоновані Ю. Борєвим [1], І. Зязюном [2], М. Каганом [5], А. Комаровою [7], В. Ліпським [8], Г. Лобковською [13], В. Лозовим [4] та ін., дозволяє розглянути цей феномен із конструктивних позицій, зауваживши при цьому його значення у розвитку суспільства, мистецтва й окремої особистості. Учені засвідчили, що естетична культура $є$ невід'ємною складовою духовного розвитку суспільства, важливим пластом художньої культури, мірою освоєння цінностей естетичної діяльності, умовою розвитку мистецтва, сукупністю матеріального, духовного і художнього життя суспільства, пов'язаного зі створенням естетично довершених творів. Дослідникам вдалося обгрунтувати діалектичний зв'язок естетичної культури з духовним розвитком суспільства, наголосити на важливості цього явища для системи освіти та виховання. Крім цього, їм вдалося дослідити становлення і розвиток естетичної культури різних соціальних груп: школярів, студентів, педагогів, митців та ін.

На наш погляд, естетична культура - це духовне утворення, інтегральний компонент загальної культури, сукупність естетичних цінностей і рівень естетичного ставлення до навколишнього світу, що характеризує здібності, таланти і потреби особистості сприймати, відчувати, оцінювати та перетворювати цей світ й саму себе “за законами краси”.

Стосовно професійної підготовки майбутніх дизайнерів зазначимо, що розвиток естетичної культури $€$ пріоритетним завданням закладів вищої освіти, адже “професійна дизайнерська діяльність, що $є$ специфічною за своїм змістом та функціями, зумовлює своєрідність вияву

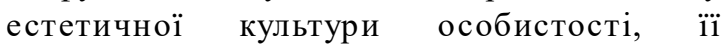
трансформацію у структуру та якість професійної культури людини" [4, 178].

У цьому контексті нам імпонують погляди В. Томашевського, який зазначає, що “естетична культура $€$ тим стрижнем, навколо якого органічно переплітаються і професійні вміння й навички, i світоглядні знання, і особистий естетичний та культурній досвід людства. Саме естетична культура майбутнього дизайнера спрямовує його в необхідне русло, свідомо керує його діяльністю... Здійснюючи значний вплив на процес професійної підготовки і становлення, естетична культура формує іншу, нову якість мислення" [10,15 - 16], яке допомагає дизайнеру естетично трансформувати сучасний світ.

На основі теоретичного аналізу наукової літератури нами пропонується визначення естетичної культури майбутнього дизайнера як інтегрального компонента естетичной 


\section{ЕСТЕТИЧНА КУЛЬТУРА МАЙБУТНІХ ФАХІВЦІВ У ГАЛУЗІ ДИЗАЙНУ: СУТНІСТЬ ТА СТРУКТУРА}

культури суспільства, особистісної якості та духовно-функціонального утворення, щзо проявлясться на рівні сформованості естетичного ставлення до навколишнього світу та його освоєння "за законами краси” у процесі творчої художньо-проектної діяльності. Власне естетична культура дизайнера $\epsilon$ головним критерієм його професійності, яка уможливлює правильний добір художніх технік, засобів і матеріалів $з$ метою якісної реалізації художнього проекту.

Як зазначалося вище, естетична культура, як i культура загалом, поняття глобальне й різномасштабне. Вона проявляється як на соціальному рівні - естетична культура суспільства, так і на індивідуальному - естетична культура особистості. Із метою розкриття структури естетичної культури звернемося до праць Г. Шевченко щодо взаємодії різних видів мистецтв в естетичному вихованні особистості. Зокрема, вона зазначає: "Естетична культура суспільства - це сукупність усіх естетичних (природних і створених працею людини) цінностей, які беруть участь у взаємодії суспільства зі світом, в прагненні суспільства до вдосконалення, повного розквіту всіх суспільних відносин" [3, 18]. Ця система забезпечує створення, зберігання, поширення і споживання естетичних цінностей.

В естетичній культурі суспільства виділяють декілька структурно-функціональних компонентів, які співвідносяться 3 чотирма рівнями (зрізами) функціонування загальної культури соціуму (див. табл. 1.).

Як видно з таблиці 1, структура естетичної культури суспільства - це складне цілісне утворення, компоненти якого знаходяться в системному взаємозв'язку. Більшість 3 них відображається у структурі естетичної культури особистості.

Естетична культура особистості, у т.ч. фахівця у галузі дизайну, у своїй структурі містить комплекс (систему) духовно-функціональних утворень, до яких учені відносять: О. Бєляєв сукупність художніх цінностей, які функціонують в суспільстві, та сукупність самостійних сфер естетичної діяльності [11]; В. Ліпський - людську чуттєвість [8]; Д. Ліхачев - естетичну свідомість та естетичну діяльність [9]; В. Лозовий естетичну свідомість, що відтворюється в ідеалах, потребах, настановах, смаках, поглядах, концепціях [4]; М. Каган - симбіоз реальнопрактичної, духовно-практичної та духовнотеоретичної діяльності, що забезпечують створення, збереження й поширення художніх цінностей [6]; I. Зязюн - естетичні об'єкти і явища, естетичні цінності, естетичні знання про їх природу та функціонування, естетичну свідомість, естетичну діяльність і ставлення, естетично спрямовану поведінку та естетичне виховання як спеціальний канал передачі підростаючому поколінню естетико-культурних засад [2].

Відповідно до компетентнісного й особистісно орієнтованого підходів виділені вченими духовнофункціональні утворення нами згруповані в емоиійно-чуттєвий, потребнісно-мотиваиійинй, когнітивний і діяльнісний компоненти естетичної культури особистості майбутнього фахівця у галузі дизайну, які перебувають у діалектичному взаємозв' язку.

Таблиця 1.

Співвідношення структурно-функціональних компонентів естетичної культури суспільства 3 рівнями функціонування загальної культури соціуму

\begin{tabular}{|l|l|}
\hline \multicolumn{1}{|c|}{$\begin{array}{c}\text { Рівні функціонування загальної } \\
\text { культури соціуму }\end{array}$} & \multicolumn{1}{|c|}{$\begin{array}{c}\text { Структурно-функціональні компоненти } \\
\text { естетичної культури }\end{array}$} \\
\hline \begin{tabular}{|l|l|} 
Матеріальний: сукупність \\
предметів людської діяльності
\end{tabular} & $\begin{array}{l}\text { Матеріальні естетичні цінності: твори мистецтва, естетичні } \\
\text { цінності утилітарно-парктичного призначення }\end{array}$ \\
\hline $\begin{array}{l}\text { Процесуальний: процес і якість } \\
\text { людської діяльності }\end{array}$ & $\begin{array}{l}\text { Естетична діяльність: практична (дизайн), художньо-практична } \\
\text { (обряди, празники), художнь-творча (створення витворів } \\
\text { мистецтва), художньо-рецептивна (сприйняття творів мистецтва), } \\
\text { рецепційно-естетична (сприйняття краси реального пейзажу), } \\
\text { духовно-культурна (вироблення ідеалів особистого смаку, } \\
\text { судження, оцінки), теоретична (естетичні концепції, теорії) }\end{array}$ \\
\hline $\begin{array}{l}\text { Ідеальний: сукупність цінностей, } \\
\text { норм, ідеалів певної соціальної } \\
\text { спільноти }\end{array}$ & $\begin{array}{l}\text { Естетична свідомість: буденне (естетичні смаки, ідеали, інтереси, } \\
\text { потреби, погляди, судження), спеціалізовані (естетичні ідеї, } \\
\text { вчення, теорії фахівців) }\end{array}$ \\
\hline $\begin{array}{l}\text { Інституціональний: сукупність } \\
\text { різних інститутів для зберігання, } \\
\text { поширення матеріальних і духовних } \\
\text { цінностей }\end{array}$ & $\begin{array}{l}\text { Система соціальних інститутів: забезпечують зберігання, } \\
\text { поширення матеріальних і духовних цінностей, передачу досвіду } \\
\text { естетичного ставлення до навколишнього світу (заклади освіти та } \\
\text { культури, засоби масової інформації, домашне виховання та ін.) }\end{array}$ \\
\hline
\end{tabular}


Когнітивна сфера особистості пов'язана 3 пізнанням естетичного розмаїття світу і виражається в естетичному світогляді (знаннях), поглядах і переконаннях, смаках та ідеалах. Вона відображає раціонально-інтелектуальний (когнітивний) рівень естетичної культури. Емоційно-чуттєва сфера естетичної культури зв'язана зі здатністю емоційно переживати i відчувати красу навколишньої дійсності. Прояв інтересудо естетично значущих предметів і явищ, що виражається у потребі сприймати i перетворювати самого себе та навколишню дійсність “за законами краси”, складає потребнісно-мотиваційну сферу естетичної культури особистості. Здатність до естетичного сприйняття та творчої естетичної діяльності складає діяльнісний компоненти естетичної культури особистості майбутнього фахівця у галузі дизайну.

Для забезпечення ефективності формування та розвитку естетичної культури майбутнього дизайнера необхідно дотримуватися низки педагогічних умов.

Першою умовою формування та розвитку естетичної культури майбутнього дизайнера $\epsilon$ наявність естетичного середовища як певної сукупності обставин, що оточують студента, виступаючи потужним чинником його входження в естетичну культуру. Високий рівень естетичної культури науково-педагогічних працівників є другою педагогічною умовою. При цьому викладач має володіти такими якостями, як: широка науково-естетична освіченість; система ціннісних орієнтацій в галузі естетики та дизайну; емоційна сприйнятливість до краси навколишнього світу, мистецтва, людських стосунків і педагогічної діяльності; наявність художньо-творчих здібностей і талантів, які дозволяють викладачеві вільно вносити естетичний елемент у різні грані освітнього процесу та творчої діяльності. Викладач, який володіє цими якостями, здатний зробити процес формування і розвитку естетичної культури майбутніх фахівців у галузі дизайну цікавим i результативним. Третя педагогічна умова організація самостійнӧ естетичної діяльності над розробленням і реалізацією творчого художнього проекту - на наш погляд, $\epsilon$ особливо важливою у процесі фахової підготовки майбутніх дизайнерів. Ця діяльність, перетворювальна за своєю суттю, задовольняє природну потребу студента у самореалізації під час створення чогось суб' єктивно або об'єктивно нового.

Висновки та перспективи подальших досліджень. Таким чином, естетична культура особистості за змістом і характером є складним соціально-історичним, культурологічним, освітнім і виховним явищем. Упродовж соціальноісторичного минулого вона засвідчила здатність людини сприймати, осмислювати і творити прекрасне в навколишньому світі та мистецтві. Естетична культура особистості сприяє акумулюванню художньо-естетичних ідей, творів, композицій, збагачує естетичний досвід митців, впливає на їхні естетичні почуття, поняття, уявлення, цінності та світогляд.

Будучи невід'ємною складовою художньотворчого процесу, естетична культура майбутнього дизайнера створює необхідні умови для глибокого сприймання, осмислення, інтерпретації художніх образів удовершені форми, відкриває простір для асоціативного, образного мислення, створення досконалих художніх проектів.

Теоретичний аналіз особливостей естетичної культури особистості майбутнього дизайнера дає змогу розглядати іiї як інтегральний компонент естетичної культури суспільства, особистісну якість та духовно-функціональне утворення, що проявляється на рівні сформованості естетичного ставлення до навколишнього світу та його освоєння "за законами краси" у процесі творчої художньо-проектної діяльності. Будучи складним системним духовно-функціональним утворенням, естетична культура майбутнього дизайнера спирається на суспільний досвід естетичного освоєння дійсності, знаходиться в стані динамічного розвитку, основою якого є механізм самоорганізації, побудований на взаємозв'язку найважливіших його компонентів - емоційночуттєвого, потребнісно-мотиваційного, когнітивного і діяльнісного.

На підставі теоретичного вивчення літературних джерел виділено три основні педагогічні умови формування і розвитку естетичної культури майбутнього дизайнера: наявність естетичного середовища; високий рівень естетичної культури науково-педагогічних працівників; організація самостійної естетичної діяльності над розробленням і реалізацією творчого художнього проекту.

Розкрита у статті сутність і структура естетичної культури майбутніх фахівців у галузі дизайну, а також виявлені педагогічні умови іiі формування та розвитку не є вичерпаними. Серед перспективних напрямів вбачаємо дослідження процесу розвитку естетичної культури майбутніх дизайнерів засобами сучасних цифрових технологій. 


\section{ЛІТЕРАТУРА}

1. Борев Ю. Б. Эстетика : учеб. пособ. Ростовна-Дону, 2004. 704 с.

2. Виховання естетичної культури школярів : навч. посібник / І. А. Зязюн, Н. С. Миропольська, Л. О. Хлєбнікова та ін. Київ, 1998. 156 с.

3. Духовно-культурні цінності виховання людини: монографія / Г.П. Шевченко, Т. Л. Антоненко, О. С. Бєлих, Є.А. Зеленов й ін Луганськ, 2013. 332 с.

4. Естетика: навч. посібник / Колесніков М.П., Колеснікова О.В., Лозовий В.О. та ін.; за ред. В.О. Лозового. Київ, 2003. 208 с.

5. Каган М. С. Начала эстетики. Москва, 1984. $210 \mathrm{c}$.

6. Каган М. С. Эстетическая культура личности. Москва, 1988. 127 с.

7. Комарова А. И. Эстетическая культура личности. Київ, 1988. 152 с.

8. Липский В. Н. Эстетическая культура и личность. Москва, 1987. 128 с.

9. Лихачев Б. Г. Теория эстетического воспитания школьников : учеб. пособ. Москва, $1985.176 \mathrm{c}$.

10. Томашевський В.В. Естетична культура як невід'ємна частина професійної підготовки майбутніх дизайнерів. Актуальні проблеми формування естетичної культури майбутніх дизайнерів: матеріали Всеукр. наук.-практ. конф. (23-24 березня 2017 р.). Кривий ріг, 2107. С. 1417.

11. Эстетика : словарь / под общ. ред. А. А. Беляева и др. Москва, 1989. 447 с

12. Эстетическая культура / рук. авт. кол. Н.И.Киященко. Москва, 1996. 201 с.

13. Эстетическая культура и эстетическое воспитание : кн. для учит. / сост. Г. С. Лобковская. Москва, 1983. 304 с.

\section{REFERENCES}

1. Borev, Yu. B. (2004). Estetika : ucheb. posob. [Aesthetics: a tutorial]. Rostov-na-Donu, 704 p. [in Russian].

2. Ziaziun, I. A., Myropolska, N. Ye. \& Khliebnikova, L. O. et al. (1998). Vykhovannia estetychnoi kultury shkoliariv : navch. posibnyk
[Education of aesthetic culture of pupils:textbook]. Kyiv, 156 p. [in Ukrainian].

3. Shevchenko, H. P.,Antonenko, T. L., Bielykh, O. S. \& Zelenov, Ye. A. et al. (2013). Dukhovno-kulturni tsinnosti vykhovannia liudyny: monohrafiia [Spiritual and cultural values of human education: monograph]. Luhansk, 332 p. [in Ukrainian].

4. Kolesnikov, M.P., Kolesnikova, O.V. \& Lozovyi, V.O. et.al. (2003). Estetyka: navch. posibnyk [Aesthetics: a tutorial]. (ed.). V.O. Lozovyi. Kyiv, 208 p. [in Ukrainian].

5. Kagan, M. S.(1984). Nachala estetiki [The beginnings ofaesthetics]. Moscov, 210 p. [in Russian].

6. Kagan, M. S. (1988). Esteticheskaya kultura lichnosti [Aesthetic personality culture]. Moscov, 127 p. [in Russian].

7. Komarova, A. I. 1988). Esteticheskaya kultura lichnosti [Aesthetic culture and personality]. Kyiv, 152 p. [in Russian].

8. Lipskiy, V. N. (1987). Esteticheskaya kultura $i$ lichnost [Aesthetic culture and personality]. Moscov, 128 p. [in Russian].

9. Likhachev, B. G. (1985). Teoriya esteticheskogo vospitaniya shkolnikov : ucheb. posob. [Theory of aesthetic education of schoolchildren: study guide]. Moscov, 176 p. [in Russian].

10. Tomashevskyi, V.V. (2017). Estetychna kultura yak nevidiemna chastyna profesiinoi pidhotovky maibutnikh dyzaineriv [Aesthetic culture as an integral part of the training of future designers]. Aktualni problemy formuvannia estetychnoi kultury maibutnikh dyzaineriv: materialy Vseukr. nauk.-prakt. konf. (23-24 bereznia 2017 r.). Actual problems of formation of aesthetic culture of future designers: Proceedings of Ukrainian Scientific and Practical Conference (March 23-24,2017). (pp.14-17). Kryvyi Rih. [in Ukrainian].

11. Estetika : slovar [Aesthetics:dictionary]. (Ed.). A. A. Belyaev et.al. Moscov, 1989. 447 p. [in Russian].

12. Esteticheskaya kultura [Aesthetic culture]. (Ed.). N.I. Kiyaschenko. Moscov, 1996. 201 p. [in Russian].

13. Esteticheskaya kultura i esteticheskoe vospitanie: $k n$. dlya uchit. [Aesthetic culture and aesthetic education: a book for teachers]. (Ed.). Lobkovskaya. Moscov, 1983. 304 p. [in Russian].

Стаття надійшла до редакції 07.06.2019

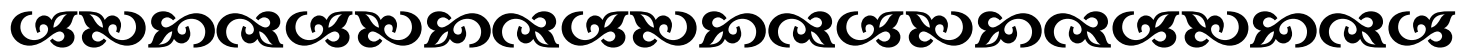

"Науку може всяқий вивчити - один з великою, інший з меншою прачею. Але ві мистецтва отримує қожен стільки, сқільки він сам в змозі дати”.

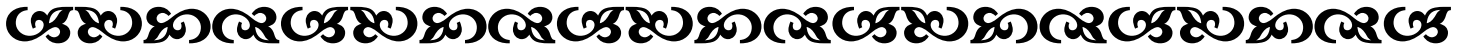

